\title{
Eurycomalactone Inhibits Expression of Endothelial Adhesion Molecules at a Post-Transcriptional Level
}

Clemens Malainer, ${ }^{\dagger}$ Daniel Schachner, ${ }^{\dagger}$ Enrico Sangiovanni, ${ }^{\dagger,}$ Atanas G. Atanasov, ${ }^{\dagger, \S \odot ~ S t e f a n ~ S c h w a i g e r, ~}{ }^{\perp}$ Hermann Stuppner, ${ }^{\perp}$ Elke H. Heiss, ${ }^{\dagger}$ and Verena M. Dirsch ${ }^{*}, \dagger$

${ }^{\dagger}$ Department of Pharmacognosy, University of Vienna, Althanstrasse 14, 1090 Vienna, Austria

${ }^{\ddagger}$ Department of Pharmacological and Biomolecular Sciences, Università degli Studi di Milano, Via Balzaretti, 9, 20133 Milano, Italy

${ }^{\S}$ Institute of Genetics and Animal Breeding of the Polish Academy of Sciences, 05-552 Jastrzebiec, Poland

${ }^{\perp}$ Institute of Pharmacy/Pharmacognosy, Center for Molecular Biosciences Innsbruck, University Innsbruck, Innrain 80/82, Innsbruck 6020, Austria

\section{Supporting Information}

ABSTRACT: The C-19 quassinoid eurycomalactone (1) has recently been shown to be a potent $\left(\mathrm{IC}_{50}=0.5 \mu \mathrm{M}\right) \mathrm{NF}-\kappa \mathrm{B}$ inhibitor in a luciferase reporter model. In this study, we show that 1 with similar potency inhibited the expression of the NF$\kappa \mathrm{B}$-dependent target genes ICAM-1, VCAM-1, and E-selectin in TNF $\alpha$-activated human endothelial cells (HUVECtert) by flow cytometry experiments. Surprisingly, $1(2 \mu \mathrm{M})$ did not inhibit $\mathrm{TNF} \alpha$-induced $\mathrm{IKK} \alpha / \beta$ or $\mathrm{I} \kappa \mathrm{B} \alpha$ phosphorylation significantly. Also, the TNF $\alpha$-induced degradation of $\mathrm{I} \kappa \mathrm{B} \alpha$ remained unchanged in response to $1(2 \mu \mathrm{M})$. In addition, pretreatment of HUVECtert with $\mathbf{1}(2 \mu \mathrm{M})$ had no statistically significant effect on $\mathrm{TNF} \alpha$-mediated nuclear translocation of the NF- $\kappa$ B subunit p65 (RelA). Quantitative RT-PCR revealed that $1(0.5-5 \mu \mathrm{M})$ exhibited diverse effects on the TNF $\alpha$ induced transcription of ICAM-1, VCAM-1, and SELE genes since the mRNA level either remained unchanged (ICAM-1, Eselectin, and VCAM-1 at $0.5 \mu \mathrm{M} \mathrm{1}$ ), was reduced (VCAM-1 at $5 \mu \mathrm{M} \mathrm{1}$ ), or even increased (E-selectin at $5 \mu \mathrm{M} 1$ ). Finally, the time-dependent depletion of a short-lived protein (cyclin D1) as well as the measurement of de novo protein synthesis in the presence of $1(2-5 \mu \mathrm{M})$ suggested that 1 might act as a protein synthesis inhibitor rather than an inhibitor of early NF- $\kappa \mathrm{B}$ signaling.

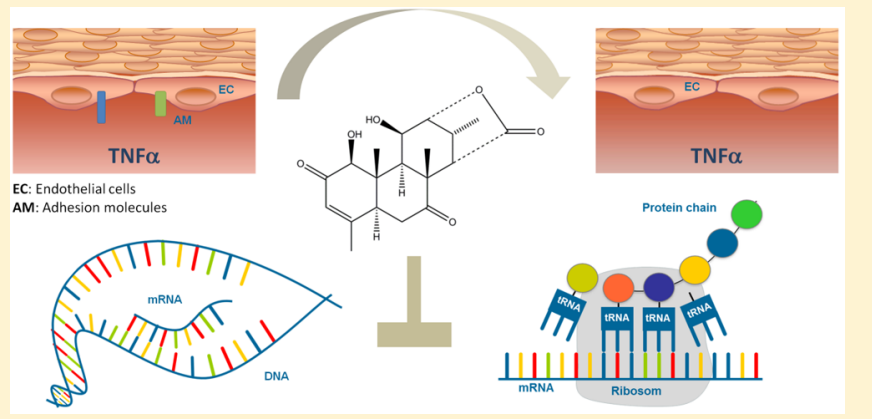

Eurycoma longifolia Jack. (Simaroubaceae) is a popular medicinal plant of Southeast Asia mainly known as Tonkat Ali. In particular root extracts are used to treat various conditions including sexual dysfunction, loss of libido, aging, stress, fatigue, impaired exercise recovery, malaria, dysentery, diarrhea, cancer, leukemia, diabetes, anxiety, high blood pressure, syphilis, or glandular swelling. Its use as an aphrodisiac and tonic for sportsmen made it also quite popular in the West. ${ }^{1,2}$ Many bioactive compounds have been isolated from E. longifolia, such as quassinoids, canthine-6-one alkaloids, $\beta$-carboline alkaloids, squalene derivatives, tirucallane-type triterpenes, biphenylneolignans, phenolic compounds, and bioactive steroids. $^{1-3}$

Via a bioguided isolation approach we recently identified several inhibitors of the transcription factor NF- $\kappa \mathrm{B}$ (nuclear factor kappa-light-chain-enhancer of activated B cells) in the roots of E. longifolia. ${ }^{3}$ One of the most interesting compounds appeared to be the C-19 quassinoid eurycomalactone ( 1 ; see Figure 1), which showed an $\mathrm{IC}_{50}$ value of $0.5 \mu \mathrm{M}$ in tumor necrosis factor (TNF) $\alpha$-activated HEK-293/NF- $\kappa$ B-luc cells, a stable cell line containing an NF- $\kappa \mathrm{B}$-driven luciferase reporter 
to the site of injury. ${ }^{4,5}$ The NF- $\kappa \mathrm{B}$ signaling pathway is activated in response to pro-inflammatory cytokines such as TNF $\alpha$ or other pro-inflammatory stimuli, such as lipopolysaccharide (LPS). ${ }^{6}$ The NF- $\kappa \mathrm{B}$ transcription factor family comprises five transcription factor proteins (p65 (RelA), c-Rel, RelB, p50, and p52) that are usually found as homo- or heterodimers. In most cell types a p65/p50 heterodimer is prevalent that is held inactive in the cytoplasm by masking its nuclear localization sequence by one of several inhibitors of $\kappa \mathrm{B}(\mathrm{I} \kappa \mathrm{B})$ proteins, of which $\mathrm{I} \kappa \mathrm{B} \alpha$ is the prototypical member. ${ }^{6,7}$ Pro-inflammatory stimuli induce a complex signaling cascade that leads to phosphorylation of the I $\kappa \mathrm{B}$ kinase (IKK) at its activation loop (Ser177 and Ser181). The phosphorylated IKK complex in turn phosphorylates $\mathrm{I} \kappa \mathrm{B}$ to tag it for degradation via the $26 \mathrm{~S}$ proteasome. The thereby unmasked NF- $\kappa \mathrm{B}$ dimer subsequently translocates to the nucleus and binds to NF- $\kappa \mathrm{B}$ response elements to initiate target gene expression. ${ }^{6,7}$

The aims of the present study were (i) to verify that $\mathbf{1}$ indeed inhibits NF- $\kappa \mathrm{B}$ target genes in a physiologically relevant model, i.e., human endothelial cells, and (ii) to determine the level of interference of $\mathbf{1}$ in the canonical NF- $\kappa$ B signaling cascade. A C20 quassinoid, eurycomanone, and a methanolic extract of $E$. longifolia roots were recently reported to inhibit NF- $\kappa \mathrm{B}$ by inhibiting the translocation of p65 to the nucleus. ${ }^{8,9}$

\section{RESULTS AND DISCUSSION}

Eurycomalactone Inhibits the Expression of TNF $\alpha$ Induced Endothelial Adhesion Molecules. Endothelial adhesion molecules, VCAM-1, ICAM-1, and E-selectin, are target gene products of NF- $\kappa \mathrm{B} .{ }^{5}$ We therefore examined the effect of $1(0.5-10 \mu \mathrm{M})$ in HUVECtert on the TNF $\alpha(10 \mathrm{ng} /$ $\mathrm{mL}$ )-induced expression of VCAM-1, ICAM-1, and E-selectin. Pretreatment with 1 (30 $\mathrm{min})$ concentration-dependently inhibited the expression of all three adhesion molecules with $\mathrm{IC}_{50}$ values of around $0.5 \mu \mathrm{M}\left(\mathrm{IC}_{50}\right.$ for VCAM-1 $=0.54 \mu \mathrm{M}$; $\mathrm{IC}_{50}$ for ICAM-1 $=0.58 \mu \mathrm{M} ; \mathrm{IC}_{50}$ for E-selectin $\left.=0.56 \mu \mathrm{M}\right)$ (Figure $2 \mathrm{~A}-\mathrm{C}$ ). These $\mathrm{IC}_{50}$ values correspond well to the $\mathrm{IC}_{50}$ value obtained in the luciferase reporter gene model that identified 1 as an NF- $\kappa \mathrm{B}$ inhibitor $\left(\mathrm{IC}_{50}=0.5 \mu \mathrm{M}\right){ }^{3}$. In the absence of TNF $\alpha, 1(0.5-10 \mu \mathrm{M})$ had no effect on basal expression levels of VCAM-1, ICAM-1, and E-selectin (Figure S1, A-C, Supporting Information).

None of the tested concentrations of $\mathbf{1}$ showed a significant impairment of cell viability compared to solvent vehicle either in the absence or presence of $\operatorname{TNF} \alpha$, although there was a tendency toward impaired viability visible at $10 \mu \mathrm{M}$ (Figure S2, Supporting Information). We therefore did not use concentrations higher than $5 \mu \mathrm{M}$ for subsequent experiments.

Eurycomalactone Does Not Interfere with the Canonical Upstream Signaling Pathway of NF- $\kappa$ B. To determine the level of interference within the NF- $\kappa \mathrm{B}$ signaling cascade, we first examined the influence of $1(2 \mu \mathrm{M})$ on TNF $\alpha(10 \mathrm{ng} /$ $\mathrm{mL}$ )-mediated $\mathrm{IKK} \alpha / \beta$ and $\mathrm{I} \kappa \mathrm{B} \alpha$ phosphorylation as well as on the degradation of $\mathrm{I} \kappa \mathrm{B} \alpha$. In HUVECtert $\mathrm{IKK} \alpha / \beta$ and $\mathrm{I} \kappa \mathrm{B} \alpha$ became phosphorylated, and thus $\mathrm{I} \kappa \mathrm{B} \alpha$ degraded after $5 \mathrm{~min}$ in response to TNF $\alpha$ stimulation (Figure $3 \mathrm{~A}-\mathrm{C}$ ). HUVECtert pretreated with $2 \mu \mathrm{M} 1$ and stimulated with TNF $\alpha$ showed no statistically significant difference compared to untreated control cells in terms of $\mathrm{IKK} \alpha / \beta$ and $\mathrm{I} \kappa \mathrm{B} \alpha$ phosphorylation as well as $\mathrm{I} \kappa \mathrm{B} \alpha$ degradation (Figure $3 \mathrm{~A}-\mathrm{C}$ ). This suggested that $\mathbf{1}$ interferes with the NF- $\kappa \mathrm{B}$ signaling cascade downstream of $\mathrm{I} \kappa \mathrm{B}$ degradation.

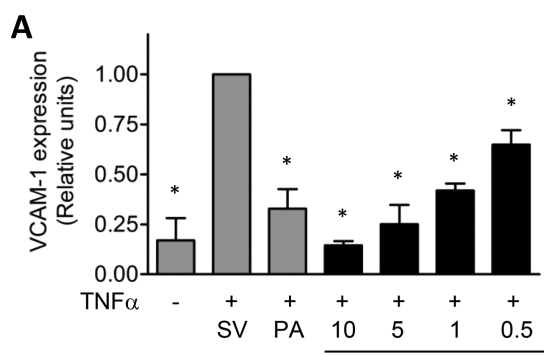

B
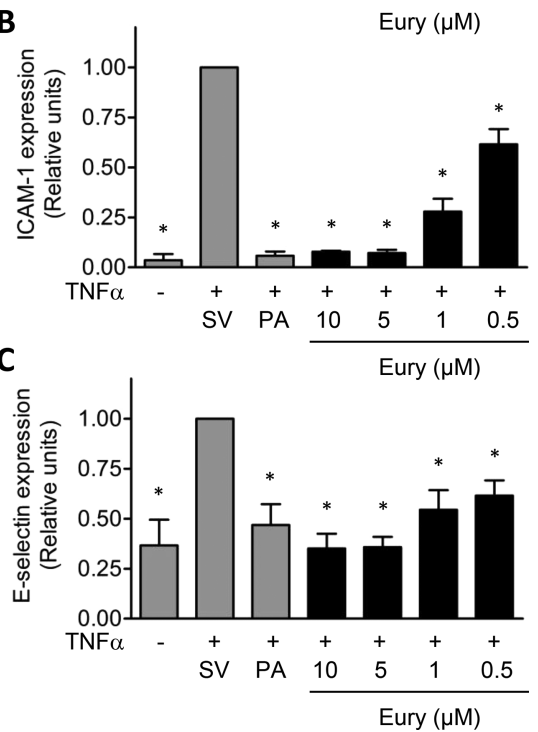

Figure 2. Eurycomalactone (1) inhibits TNF- $\alpha$-induced cell surface expression of the endothelial adhesion molecules VCAM-1 (A), ICAM-1 (B), and E-selectin (C) in HUVECtert endothelial cells. HUVECtert were pretreated with the indicated concentrations of 1 or solvent vehicle (SV) as control for $30 \mathrm{~min}$ prior to stimulation with $\mathrm{TNF} \alpha(10 \mathrm{ng} / \mathrm{mL})$ for $18 \mathrm{~h}$ (VCAM-1, ICAM-1) or $5 \mathrm{~h}$ (E-selectin). Parthenolide at $10 \mu \mathrm{M}(\mathrm{PA})$ was used as positive control. Protein expression levels were analyzed by flow cytometry. Data shown are means $\pm \mathrm{SD}(n=3 ; * P<0.05$, one-way ANOVA/Dunnet's versus solvent vehicle control).

Next, we tested whether 1 interferes with the translocation of NF- $\kappa \mathrm{B}$ to the nucleus. To this end, we prepared nuclear protein extracts of cells that had been pretreated with $1(2 \mu \mathrm{M}, 30 \mathrm{~min})$ or solvent vehicle and were then stimulated with TNF $\alpha$ for $1 \mathrm{~h}$. Figure 4 shows that nuclear p65 protein level increases in response to TNF $\alpha$. Interestingly, $1(2 \mu \mathrm{M})$ was not able to inhibit this translocation. Also, the binding of p 65 to an NF- $\kappa$ B DNA consensus sequence was not blocked by $\mathbf{1}$ (data not shown). This suggests that $\mathbf{1}$ acts further downstream possibly by inhibiting transcription or translation of the NF- $\kappa$ B target gene products VCAM-1, ICAM-1, and E-selectin. These findings appear to be in contrast to a recent report that stated that a methanolic extract of E. longifolia roots inhibits translocation of p65 to the nucleus in LPS-activated RAW264.7 macrophages. However, other compounds besides 1 might be responsible for this effect. ${ }^{9}$ That study shows also that the overall p65 protein level in RAW264.7 cells strongly declines in the presence of the E. longifolia extract compared to LPS control. Thus, reduced p65 level in the nucleus could be also explained by a reduced expression of $\mathrm{p} 65$ in response to $E$. longifolia extract or simply due to cytotoxicity since the authors do not provide viability data of their cells. Another report shows that the C-20 quassinoid eurycomanone (45 $\mu \mathrm{M})$ inhibits the NF- $\kappa \mathrm{B}$ signaling pathway by inhibiting the 


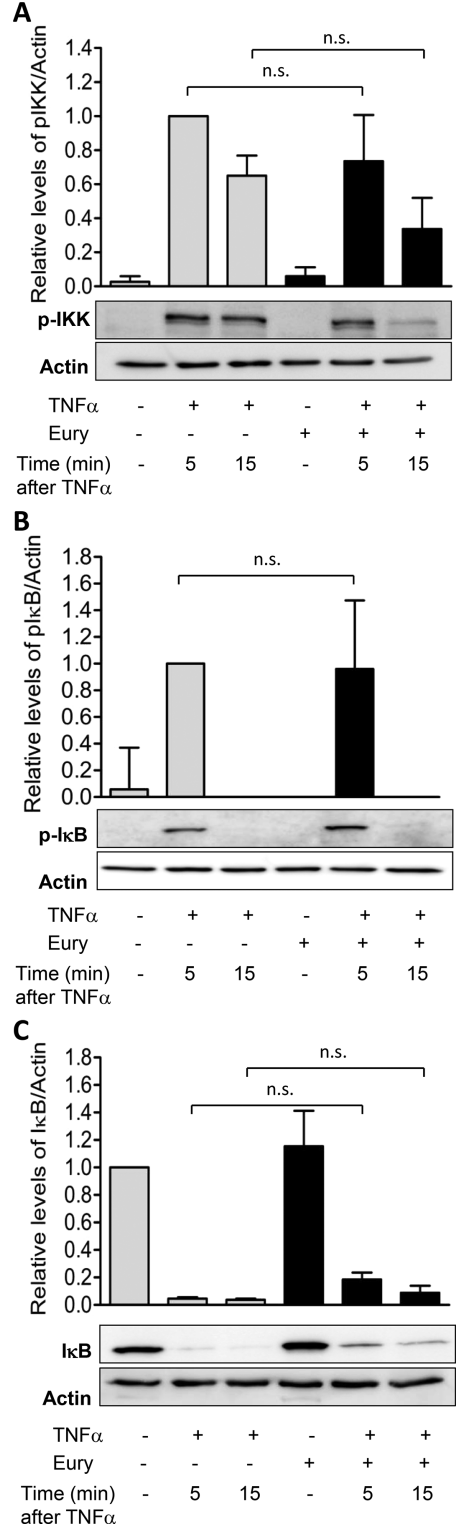

Figure 3. Eurycomalactone (1) does not impair phosphorylation of $\mathrm{IKK}$ or $\mathrm{I} \kappa \mathrm{B}$ as well as $\mathrm{I} \kappa \mathrm{B}$ degradation in $\mathrm{TNF} \alpha$-stimulated HUVECtert endothelial cells. HUVECtert were pretreated with 2 $\mu \mathrm{M} 1$ or solvent vehicle as control prior to stimulation with TNF $\alpha(10$ $\mathrm{ng} / \mathrm{mL}$ ) for 30 min. p-IKK (A), p-I $\kappa \mathrm{B}(\mathrm{B})$, and $\mathrm{I} \kappa \mathrm{B}(\mathrm{C})$ levels were detected by Western blot analyses 5 or 15 min after TNF $\alpha$ stimulation as indicated. Actin was used as loading control. Data shown are means $\pm \mathrm{SD}(n=3$; n.s. $=$ not significant, one-way ANOVA/Dunnet's).

phosphorylation of $\mathrm{I} \kappa \mathrm{B} \alpha$ and subsequent translocation of $\mathrm{p} 65$ to the nucleus in TNF $\alpha$-activated Jurkat T cells. ${ }^{8}$ The authors argue that the presence of a lactone function and the $\alpha, \beta$ unsaturated ketone group in eurycomanone might account for the NF- $\kappa \mathrm{B}$ inhibitory effects as shown for other NF- $\kappa$ B inhibitors. ${ }^{8}$ Although both functions are present in $\mathbf{1}$, no inhibition of NF- $\kappa \mathrm{B}$ nuclear translocation and DNA binding was observed.

Eurycomalactone Does Not Inhibit mRNA Expression of Endothelial Cell Adhesion Molecules. To test whether 1 interferes with the transcription of endothelial adhesion molecules, we determined the mRNA level of VCAM-1, ICAM-1, and E-selectin in HUVECtert pretreated with 0.5 and $5 \mu \mathrm{M} 1$ and stimulated with $\mathrm{TNF} \alpha(10 \mathrm{ng} / \mathrm{mL})$ for $4 \mathrm{~h}$

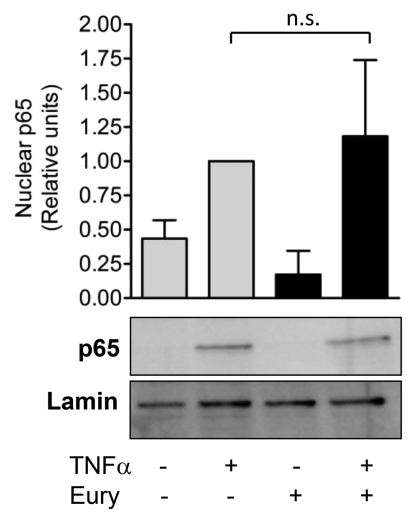

Figure 4. Eurycomalactone (1) does not impair nuclear translocation of p65 in TNF $\alpha$-stimulated HUVECtert endothelial cells. HUVECtert were pretreated with $2 \mu \mathrm{M} 1$ or solvent vehicle as control for $30 \mathrm{~min}$ prior to stimulation with $\mathrm{TNF} \alpha(10 \mathrm{ng} / \mathrm{mL})$. After $1 \mathrm{~h}$ of stimulation nuclear protein extracts were prepared and p65 levels detected by Western blot analyses. Lamin was used as loading control. Data shown are means $\pm \mathrm{SD}(n=3$, n.s. = not significant, one-way ANOVA/ Dunnet's).

(VCAM-1, ICAM-1) and $2 \mathrm{~h}$ (E-selectin), respectively. As a positive control we used the NF- $\kappa \mathrm{B}$ inhibitor parthenolide (10 $\mu \mathrm{M})$ and on the other side the protein synthesis inhibitor cycloheximide (at the standard concentration of $10 \mu \mathrm{g} / \mathrm{mL}$ corresponding to $35 \mu \mathrm{M}$ ) since quassinoids are reported to act as protein synthesis inhibitors in eukaryotic cells by targeting ribosomal peptidyl transferase. ${ }^{10}$ Whereas parthenolide completely inhibited TNF $\alpha$-induced mRNA expression of VCAM1, ICAM-1, and E-selectin, the effect in the presence of 1 appeared more complex (Figure 5): 1 had no effect on $\operatorname{TNF} \alpha$ induced ICAM-1 mRNA level. TNF $\alpha$-induced VCAM-1 mRNA expression was inhibited in the presence of $5 \mu \mathrm{M} 1$ but not affected by $0.5 \mu \mathrm{M}$ 1. TNF $\alpha$-induced E-selectin expression even increased in the presence of $5 \mu \mathrm{M} 1$ but was not affected by $0.5 \mu \mathrm{M}$ of 1 . Thus, overall $0.5 \mu \mathrm{M} 1 \mathrm{did}$ not influence endothelial adhesion molecule mRNA expression, whereas a higher concentration $(5 \mu \mathrm{M})$ reduced $\mathrm{TNF} \alpha$ induced VCAM-1, increased E-selectin, and did not change ICAM-1 mRNA level. Comparison with the protein synthesis inhibitor cycloheximide shows a similar but not identical pattern: $35 \mu \mathrm{M}$ cycloheximide inhibits TNF $\alpha$-induced VCAM1 , but increases ICAM-1 and E-selectin mRNA expression, which is in agreement with previously published data. ${ }^{5,11-13}$ The observation that mRNA levels of the adhesion molecules ICAM-1 and E-selectin (ELAM-1) increase in response to protein synthesis inhibition was observed earlier and explained by labile proteins that regulate (in this case decrease) mRNA stability. ${ }^{12,14}$ Protein synthesis inhibition thus will lead to increased mRNA level. ${ }^{15}$ These data suggest that $\mathbf{1}$ might act at a post-transcriptional level as reported earlier for quassinoids. ${ }^{10,16}$

As a next step, we tested whether cycloheximide is able to inhibit VCAM-1 protein expression in our hands and to determine the concentration that appears equally effective to 1 in order to allow comparison of both compounds in subsequent experiments. Concentration-response experiments (Figure 6) revealed that cycloheximide effectively inhibits VCAM-1 expression at $0.035-3.5 \mu \mathrm{M}\left(\mathrm{IC}_{50} \approx 0.3 \mu \mathrm{M}\right)$.

Eurycomalactone Acts as Protein Synthesis Inhibitor. We therefore compared $1\left(2 \mu \mathrm{M}, \sim 4 \times \mathrm{IC}_{50}\right)$ and the protein synthesis inhibitor cycloheximide $(1 \mu \mathrm{M})$ regarding their 

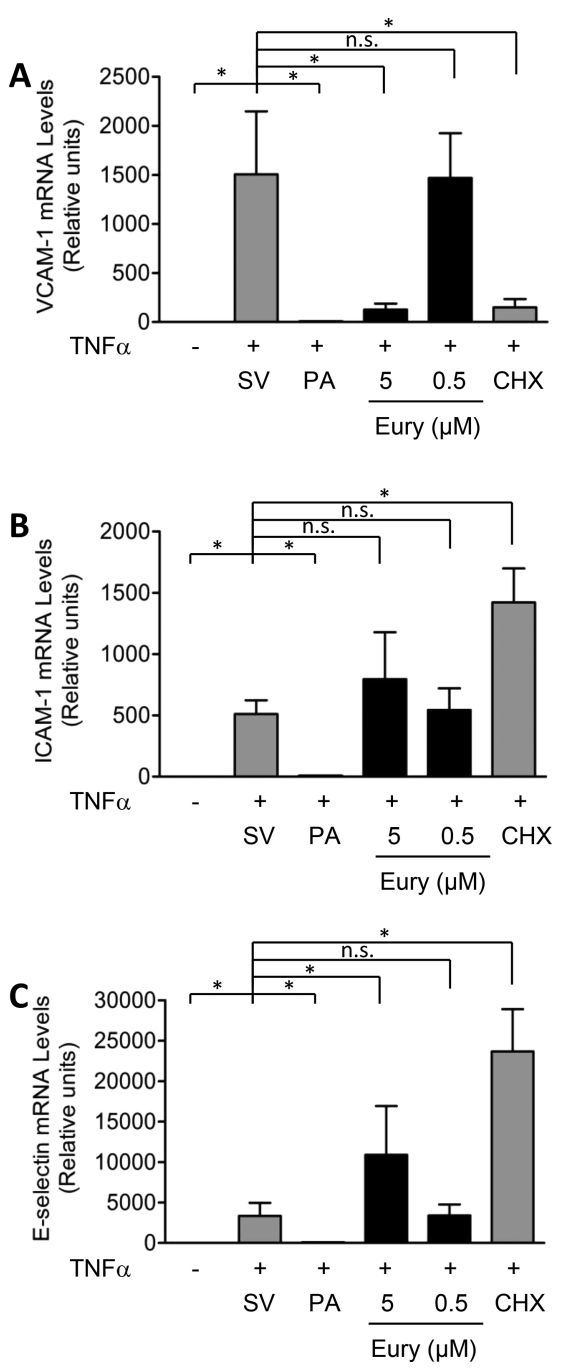

Figure 5. Eurycomalactone (1) decreases mRNA level of VCAM-1 at $5 \mu \mathrm{M}$ (A) but does not inhibit mRNA expression of endothelial adhesion molecules VCAM-1 at $0.5 \mu \mathrm{M}$ (A) or ICAM-1 (B) and Eselectin (C) at 0.5 and $5 \mu \mathrm{M}$ in HUVECtert endothelial cells. HUVECtert were pretreated with the indicated concentrations of 1 or solvent vehicle (SV) as control for $30 \mathrm{~min}$ prior to stimulation with $\mathrm{TNF} \alpha(10 \mathrm{ng} / \mathrm{mL})$ for $4 \mathrm{~h}$ (VCAM-1, ICAM-1) or $2 \mathrm{~h}$ (E-selectin). Parthenolide (PA, $10 \mu \mathrm{M})$ was used as positive control for NF- $\kappa \mathrm{B}$ inhibition and cycloheximide ( $\mathrm{CHX}, 35 \mu \mathrm{M})$ as positive control for protein synthesis inhibition. mRNA expression levels were analyzed by qRT-PCR. Data shown are means \pm SD $(n=3$; n.s. = not significant; $* P<0.05$, paired $t$ test, two-tailed).

influence on protein levels of short-lived proteins in timecourse experiments by Western blot analysis. Figure 7A/B show that the level of cyclin D1, which has a half-life of about 24 min, ${ }^{17}$ is significantly reduced after $30 \mathrm{~min}$ of incubation with cycloheximide or $\mathbf{1}$, although cycloheximide compared to $\mathbf{1}$ elicited an apparently more pronounced decay. Interestingly, survivin, with a similar half-life $(\sim 30 \mathrm{~min})^{18}$ to cyclin D1, was less responsive to cycloheximide (significant inhibition after $240 \mathrm{~min}$ ), and 1 did not show an effect at all on survivin levels (Figure 7C/D). Additional proteins we have examined are p53 and cyclin $A$, with reported half-lives of $\sim 5-20 \mathrm{~min}^{19}$ and $\geq 12$ $\mathrm{h},{ }^{20}$ respectively. Neither cycloheximide nor 1 affected their protein level in HUVECtert within the chosen time frame $(8 \mathrm{~h})$ (data not shown). Reasons for this are most likely the half-life of cyclin A, which exceeds $8 \mathrm{~h}$, and the cell type we used. ${ }^{19}$

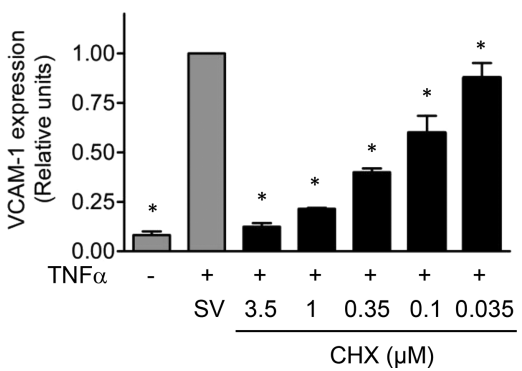

Figure 6. Cycloheximide inhibits TNF- $\alpha$-induced VCAM-1 expression in HUVECtert endothelial cells. HUVECtert were pretreated with the indicated concentrations of cycloheximide ( $\mathrm{CHX}$ ) or solvent vehicle (SV) as control for $30 \mathrm{~min}$ prior to stimulation with $\mathrm{TNF} \alpha(10 \mathrm{ng} /$ $\mathrm{mL}$ ) for $18 \mathrm{~h}$ (VCAM-1). Protein expression levels were analyzed by flow cytometry. Data shown are means $\pm \mathrm{SD}(n=3 ; * P<0.05$, oneway ANOVA/Dunnet's versus solvent vehicle control).

mRNA levels of cyclin D1 were not affected in response to cycloheximide $(1 \mu \mathrm{M})$ or $\mathbf{1}(2 \mu \mathrm{M})$ (Figure S3, Supporting Information), corroborating inhibition of a post-transcriptional step as a reason for the reduced cyclin D levels. To get a clearer picture, we employed a Click-iT protein synthesis assay. This assay uses $O$-propargyl-puromycin (OPP), which is efficiently incorporated into newly synthesized proteins. After incorporation, fluorescent Alexa Fluor 488 picolyl azide is added and ligated to the OPP alkyne, allowing the modified proteins to be detected by image-based analysis. Since the incubation time for this assay is rather short (30 $\mathrm{min})$, we applied higher concentrations of both compounds: $1-35 \mu \mathrm{M}$ cycloheximide and $2-5 \mu \mathrm{M} 1$. To allow quantification, next to fluorescence detection by confocal microscopy we quantified Alexa Fluor 488 fluorescence also by flow cytometric analysis (Figure 8A/ B). Both compounds inhibited de novo protein synthesis significantly, although $\mathbf{1}$ appeared to be slightly less effective than cycloheximide. Altogether, the presented data suggest that 1 acts as a protein synthesis inhibitor. This mechanism may at least contribute to the inhibition of luciferase gene expression as observed in our previous publication ${ }^{3}$ and reduced endothelial adhesion molecules as shown in Figure 2. Quassinoids were reported in the 1970s and early 1980s to bind to the peptidyl transferase center of ribosomes inhibiting peptide bond formation in eukaryotes, thus acting as elongation inhibitors. $^{21,22}$ Actively synthesizing ribosomes will continue protein synthesis and need to terminate before quassinoids bind. $^{23-25}$ Silva et al. quite recently reported that the quassinoid isobrucein $\mathrm{B}$ isolated from the Amazonian medicinal plant Picrolemma sprucei exerted in vivo and in vitro anti-inflammatory activity. ${ }^{26}$ They showed that isobrucein B inhibits the release of pro-inflammatory cytokines in LPS-activated primary murine peritoneal macrophages in a concentration-dependent manner within a similar concentration range to that used in our study $(0.1-10 \mu \mathrm{M})$. Interestingly, isobrucein $\mathrm{B}$ was unable to interfere with the NF- $\kappa \mathrm{B}$ signaling pathway in LPS-activated RAW264.7 macrophages; the mRNA levels of the NF- $\kappa$ B target gene TNF also remained unaffected. Since isobrucein B inhibited luciferase activity also in RAW264.7 macrophages transfected with a luciferase reporter gene that was under the control of a constitutively acting promotor, the authors concluded that isobrucein $\mathrm{B}$ might be acting nonspecifically through modulation of a post-transcriptional mechanism, probably inhibition of protein synthesis. ${ }^{26}$ The number of publications addressing quassinoids as potential NF- $\kappa \mathrm{B}$ 

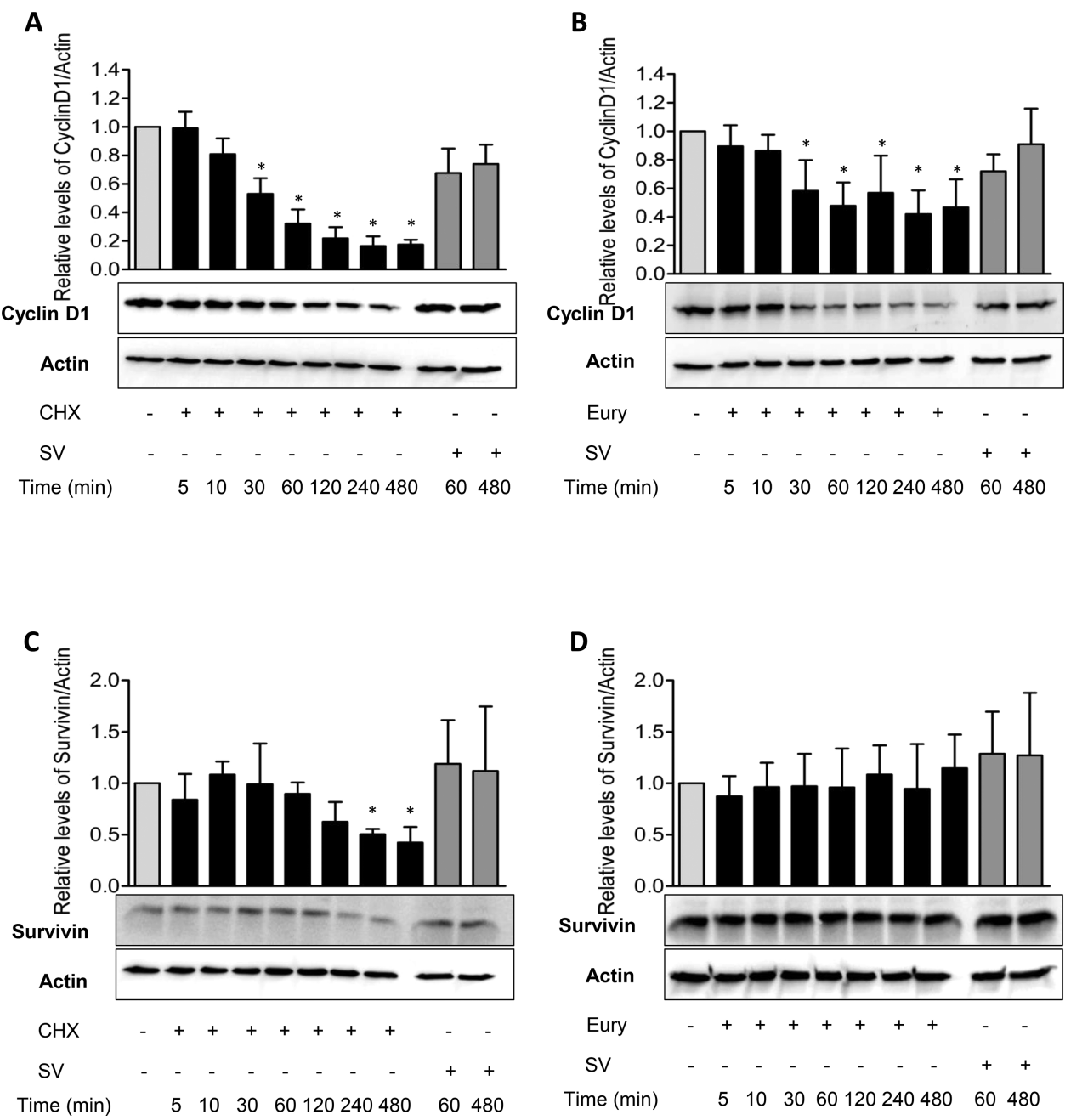

Figure 7. Time-dependent effect of eurycomalactone (1) or cycloheximide on the protein levels of cyclin D1 and survivin. Cells were left untreated or incubated with cycloheximide $(1 \mu \mathrm{M}, \mathrm{CHX}), 1(2 \mu \mathrm{M}$, Eury), or solvent vehicle (SV) for the indicated time. Then cells were harvested, and Western blot analysis was performed using antibodies against cyclin D1 (A, B) or survivin (C, D). Actin was used as loading control. A representative Western blot out of three is shown. Bar graphs show means $\pm \mathrm{SD}(n=3 ; * P<0.05$, one-way ANOVA/Dunnet's versus untreated control).

inhibitors is currently quite limited. ${ }^{3,8,26-29}$ The available data indicate that isobrucein $\mathrm{B}(10 \mu \mathrm{M}$, LPS-activated murine macrophages), eurycomalactone $(2 \mu \mathrm{M}, \mathrm{TNF} \alpha$-activated HUVECtert), eurycomanol (100 $\mu \mathrm{M}, \mathrm{TNF} \alpha$-activated Jurkat $\mathrm{T}$ cells), and brusatol (50 $\mathrm{nM}, \mathrm{IL}-1 \beta$ activated murine insulinoma-derived $\beta$ TC6 cells) do not interfere with NF- $\kappa \mathrm{B}$ p65 translocation to the nucleus, whereas eurycomanone (45 $\mu \mathrm{M}, \mathrm{TNF} \alpha$-activated Jurkat T cells) and brucein $\mathrm{D}(3-30 \mu \mathrm{M}$, PANC-1 pancreatic cancer cells) do. ${ }^{8,26,28,29}$ Thus, eurycomanone is the only quassinoid shown to inhibit the NF- $\kappa \mathrm{B}$ signaling cascade in a cytokine-activated cellular model. Quassinoids have also been reported to inhibit the transcription factors Nrf2 and AP-1. ${ }^{30-32}$ Ren et al. reported that brusatol (but not brucein $\mathrm{C}$ ) inhibits Nrf2 at nanomolar concentrations in various cancer cell lines by reducing its protein level through enhanced ubiquitination and degradation of $\mathrm{Nrf} 2 .^{30} \mathrm{Nrf} 2$ depletion in response to brusatol was verified by Olayanju et al. $^{31}$ They highlighted the specificity of brusatol $(300 \mathrm{nM})$ for Nrf2 and postulated a post-transcriptional mechanism that does not involve enhanced proteasomal or autophagic degradation of Nrf2. ${ }^{31}$ A recent proteome analysis in the non-small-cell lung cancer cell line A549 identified brusatol (500 nM) as a global protein synthesis inhibitor. ${ }^{33}$ Beutler et al. addressed the potential of quassinoids to inhibit the transcription factor AP$1 .^{32}$ They identified ailanthinone, glaucarubinone, and $6 \alpha$ senecionylchaparrin as potent AP-1 inhibitors in a luciferase reporter model. The activity, however, appeared not to be specific since NF- $\kappa$ B and serum response element (SRE)-driven gene transactivation was also inhibited. Measurement of de novo protein synthesis showed no clear correlation between AP-1 inhibition and protein synthesis inhibition. ${ }^{32}$ Also in the present study, the concentrations sufficient to inhibit an NF- $\kappa \mathrm{B}$-driven target gene $\left(\mathrm{IC}_{50}=0.5 \mu \mathrm{M}\right)$ was lower than that leading to significant protein synthesis inhibition $(2 \mu \mathrm{M})$. Thus, it cannot be excluded that next to protein synthesis inhibition additional mechanisms may contribute to the in vitro anti-inflammatory effect of 1 .

The differences in the described effects of some investigated quassinoids might also be a result of the structural heterogeneity within this compound class, which is currently subdivided into C-18, C-19, C-20, C-22, and C-25 types. ${ }^{10}$ Unfortunately larger SAR studies were only carried out using C-20-type quassinoids ${ }^{22,34,35}$ and are missing to our knowledge for the other subtypes. Therefore, the impact of changes in the total number of carbons and shape of the basic skeletons remains rather unclear and seems to be even more complex 


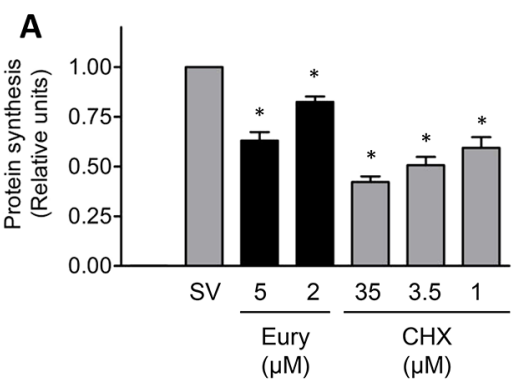

B

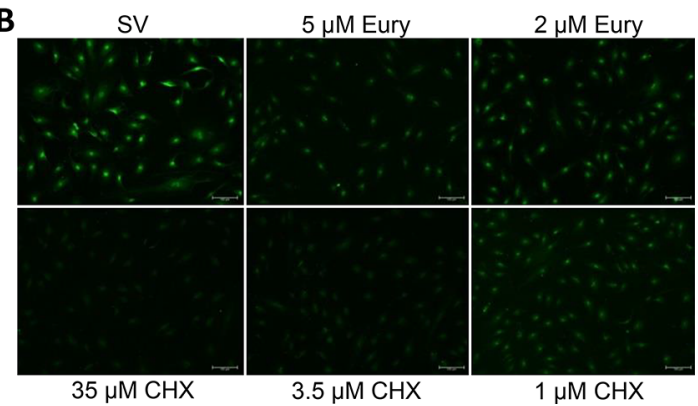

Figure 8. Eurycomalactone (1) inhibits de novo protein synthesis. Cells were incubated with cycloheximide $(1-35 \mu \mathrm{M}, \mathrm{CHX}), 1(2$ or $5 \mu \mathrm{M}$, Eury), or solvent vehicle (SV) for $30 \mathrm{~min}$, and then Click-iT OPP reagent was added for $30 \mathrm{~min}$. Further staining was performed as described in the Experimental Section. Samples were analyzed by flow cytometry $(n=3 ; * P<0.05$, one-way ANOVA/Dunnet's versus solvent vehicle control) and confocal fluorescence microscopy (B). Representative pictures are shown.

since Kupchan et al. showed that the antileukemic activity of the bruceolide derivatives already varies widely with differences in the ester substituent. ${ }^{36}$

In conclusion, we find eurycomalactone to be a highly interesting natural product that warrants further research. Possibly new approaches including ribosome profiling as used previously to shed new light on the mechanism of action of macrolide antibiotics will show how specific or unspecific quassinoids in general and/or eurycomalactone in particular act on eukaryotic protein synthesis. ${ }^{37,38}$

\section{EXPERIMENTAL SECTION}

Cell Culture. Immortalized human umbilical vein endothelial cells (HUVECtert) $^{39}$ (kindly provided by H. Stockinger, Medical University of Vienna, Austria) were used until passage 15 in basal endothelial cell growth medium with phenol red (Lonza, Switzerland). The medium was supplemented with $100 \mathrm{U} / \mathrm{mL}$ benzylpenicillin (Lonza, Switzerland), $100 \mu \mathrm{g} / \mathrm{mL}$ streptomycin (Lonza, Switzerland), $1 \%$ amphotericin B (Lonza, Switzerland), 10\% fetal bovine serum (Gibco, Germany), and the following SingleQuots from Lonza, Switzerland: hEGF, hydrocortisone, gentamicin, bovine brain extract, and ascorbic acid. Cells were cultured at $37{ }^{\circ} \mathrm{C}$ and $5 \% \mathrm{CO}_{2}$ in a humidified atmosphere in precoated $(0.1 \%$ gelatin in phosphatebuffered saline, PBS) cell culture flasks. Control cells were always treated with an equal volume of solvent.

Cell Viability. Cells were seeded into precoated $(0.1 \%$ gelatin in PBS) 48-well plates at a density of $2 \times 10^{4}$ cells/well and grown for 48 $\mathrm{h}$. Then cells were incubated with either medium alone or medium supplemented with solvent vehicle (0.1\% DMSO), the indicated concentrations of $\mathbf{1}$, or digitonin as a positive control $(100 \mu \mathrm{g} / \mathrm{mL})$. After $18 \mathrm{~h}$ supernatants were removed, and cells washed once with PBS and then incubated for $2 \mathrm{~h}$ with $10 \mu \mathrm{g} / \mathrm{mL}$ Resazurin (SigmaAldrich, Austria) in PBS. Metabolic activity through conversion of resazurin was measured as an increase in fluorescence at a wavelength of $590 \mathrm{~nm}$ (excitation wavelength: $535 \mathrm{~nm}$ ) using a multiplate reader (Tecan, Austria). Results are shown relative to the conversion rate of the solvent vehicle treatment.

Flow Cytometry. Flow cytometric measurements were performed as described previously. ${ }^{40}$ FITC-labeled antibodies (anti-VCAM-1 (BD Biosciences, Vienna, Austria), anti-ICAM-1, and anti-E-selectin (eBioscience, Vienna, Austria)) were used to stain cells for analysis with a FACSCalibur (BD Biosciences, Vienna, Austria) flow cytometer. Results are shown relative to the expression levels of adhesion molecules of TNF $\alpha$-stimulated control cells.

SDS-Polyacrylamide Electrophoresis and Immunoblot Analysis. Cells were seeded into precoated (0.1\% gelatin in PBS) $10 \mathrm{~cm}$ dishes at a density of $0.5 \times 10^{6}$ cells for the indicated time and then preincubated with $1(2 \mu \mathrm{M})$, cycloheximide $(1 \mu \mathrm{M})$, or solvent vehicle $(0.1 \% \mathrm{DMSO})$ and subsequently stimulated with $\mathrm{TNF} \alpha(10 \mathrm{ng} / \mathrm{mL})$ where indicated. Protein extraction, SDS-polyacrylamide electrophoresis, and immunoblot analysis was performed as described. ${ }^{41}$ For immunoblot analysis the following antibodies were used: anticyclin $\mathrm{D}$, anti-survivin, anti-I $\kappa \mathrm{B} \alpha$, anti-phospho-IKK $\alpha / \beta$, anti-phospho$\mathrm{I} \kappa \mathrm{B} \alpha$, and anti-p65 (Cell Signaling Technology, Danvers, MA, USA), anti-p53 (Delta Biolabs, Gilroy, CA, USA), anti-cyclin A (Santa Cruz Biotechnology, Santa Cruz, CA, USA), anti-lamin (Abcam, Cambridge, UK), anti-actin (MP Biomedicals, Illkirch, France), and anti-tubulin (Santa Cruz Biotechnology). All antibodies were diluted following the recommendation of the providing company. Results are shown relative to the protein levels of unstimulated control cells.

mRNA Isolation and Quantitative RT-PCR (qRT-PCR). A total of $0.5 \times 10^{6}$ cells were grown in precoated ( $0.1 \%$ gelatin in PBS) 10 $\mathrm{cm}$ dishes for $48 \mathrm{~h}$ and then preincubated for $30 \mathrm{~min}$ with either 1 (5 or $0.5 \mu \mathrm{M})$, parthenolide $(10 \mu \mathrm{M})$, cycloheximide $(10 \mu \mathrm{g} / \mathrm{mL}$ to 35 $\mu \mathrm{M})$, or solvent vehicle (0.1\% DMSO) and stimulated with TNF $\alpha(10$ $\mathrm{ng} / \mathrm{mL}$ ) for $4 \mathrm{~h}$ (VCAM-1 and ICAM-1) or $2 \mathrm{~h}$ (E-selectin). For cyclin D1 quantification cells were incubated with either $1(2 \mu \mathrm{M})$, cycloheximide $(1 \mu \mathrm{M})$, or solvent vehicle $(0.1 \% \mathrm{DMSO})$ for $0.5-4 \mathrm{~h}$. RNA isolation and subsequent cDNA synthesis were performed according to the instructions of the respective kit manufacturer (Peqlab, VWR International GmbH, Erlangen, Germany). The realtime SybrGreen-based quantitative PCR was carried out in a reaction volume of $15 \mu \mathrm{L}$ (30 ng). Forward and reverse primer mixtures for human VCAM-1, human ICAM-1, human E-selectin, and human cyclin D1 as target genes were obtained from Qiagen (Qiagen, Hilden, Germany). Reference gene human 18S RNA was obtained from Qiagen (Qiagen, Hilden, Germany), and human actin B (fwd: TCA AGG TGG GTG TCT TTC CT; rev: CTG CTG TCA CCT TCA CCG TT) was obtained from Invitrogen (Carlsbad, CA, USA). PCR contained one denaturation step $\left(5 \min\right.$ at $\left.95{ }^{\circ} \mathrm{C}\right)$ and up to 55 amplification cycles (denaturation: $10 \mathrm{~s}$ at $95{ }^{\circ} \mathrm{C}$, annealing $20 \mathrm{~s}$ at 55 ${ }^{\circ} \mathrm{C}$, and elongation $30 \mathrm{~s}$ at $72{ }^{\circ} \mathrm{C}$ ). Melting curves of the amplified DNA were analyzed to make sure that the PCR resulted in amplification of one specific product only, which was reconfirmed by a single distinct band on an agarose gel. Data were analyzed using Light Cycler LC480 software (Roche Diagnostics, Vienna, Austria) and the $2^{-\Delta \Delta \mathrm{Ct}}$ method.

Click-iT OPP Alexa Fluor488 Protein Synthesis Assay for Confocal Fluorescence Microscope. All described Click-iT reagents and Nuclear Mask were part of the Click-iT OPP Alexa Fluor 488 protein synthesis assay kit (Invitrogen). Cells were seeded at a density of $8 \times 10^{4}$ cells/well onto gelatin-coated coverslips in 12-well plates for $24 \mathrm{~h}$. On the following day, cells were stimulated with 1 (5 or $2 \mu \mathrm{M})$, cycloheximide $(35,3.5$, or $1 \mu \mathrm{M})$, or solvent vehicle $(0.1 \%$ DMSO) for $30 \mathrm{~min}$. After preincubation, $20 \mu \mathrm{M}$ Click-iT OPP reagent was added for a further $30 \mathrm{~min}$. The coverslips were washed once with PBS and fixed with 3.7\% formaldehyde in PBS (Sigma-Aldrich, Vienna, Austria) for $15 \mathrm{~min}$ followed by permeabilization with $0.5 \%$ Triton X100 in PBS (Sigma-Aldrich, Vienna, Austria) for a further $15 \mathrm{~min}$ at room temperature. After two washing steps with PBS, the coverslips were light-protected incubated with freshly prepared Click-iT Plus OPP Alexa 488 reaction cocktail for $30 \mathrm{~min}$. To remove excess reaction cocktail, coverslips were washed once with Click-iT reaction 
rinse buffer followed by DNA staining with Nuclear Mask Blue Stain for $30 \mathrm{~min}$. The coverslips were washed twice with PBS and mounted on a glass slide using Fluoromount mounting medium (Sigma-Aldrich, Vienna, Austria). After drying for $2 \mathrm{~h}$ at room temperature the specimens were analyzed by using the fluorescence unit of the confocal fluorescence microscope (Leica Microsystems, Wetzlar, Germany). All samples were detected with $10 \times$ magnification, constant gain, and exposure time.

Click-iT OPP Alexa Fluor488 Protein Synthesis Assay for Flow Cytometer. All described Click-iT reagents were part of the Click-iT OPP Alexa Fluor 488 protein synthesis assay kit (Invitrogen, Carlsbad, CA, USA). Detailed sample preparation occurred as described above. Cells were seeded at a density of $1 \times 10^{6}$ cells directly into flow cytometer tubes and centrifuged for $4 \mathrm{~min}$ at $274 \mathrm{~g}$. After stimulation and incubation with Click-iT OPP reagent cells were fixed and permeabilized. Afterward, cells were washed twice with wash buffer (24.8 mM Tris base, $190 \mathrm{mM} \mathrm{NaCl}, 1 \%$ Tween 20, $\mathrm{pH} 7.4$ ) and light-protected-incubated with freshly prepared Click-iT Plus OPP Alexa 488 reaction cocktail. Excess reaction cocktail was removed by washing the tubes once with Click-iT reaction rinse buffer and two times with wash buffer. Cells were resuspended in assay buffer (24.8 $\mathrm{mM}$ Tris base, $190 \mathrm{mM} \mathrm{NaCl}, \mathrm{pH}$ 7.4) and directly measured with a FACSCalibur (BD Biosciences, Vienna, Austria) flow cytometer (FL-1 channel). Results are shown relative to the protein synthesis levels of control cells.

Nuclear Translocation of NF- $\kappa$ B p65. A total of $0.5 \times 10^{6}$ cells were grown in precoated ( $0.1 \%$ gelatin in PBS) $10 \mathrm{~cm}$ dishes for $48 \mathrm{~h}$ and then preincubated for $30 \mathrm{~min}$ with either $1(2 \mu \mathrm{M})$ or solvent vehicle $(0.1 \% \mathrm{DMSO})$. Then, where indicated, TNF $\alpha(10 \mathrm{ng} / \mathrm{mL})$ was added for $1 \mathrm{~h}$.

To separate nuclear from cytosolic proteins, the dishes were first washed with cold PBS and then treated with $200 \mu \mathrm{L}$ of buffer 1 (10 mM HEPES pH 7.5, $0.2 \mathrm{mM}$ EDTA, $10 \mathrm{mM} \mathrm{KCl}, 1 \% \mathrm{NP} 40$ (Igepal), $1 \mathrm{mM}$ DTT, $0.5 \mathrm{mM}$ PMSF, Complete (Roche, Switzerland)). Cells were scraped together, transferred into a microtube, and incubated for $15 \mathrm{~min}$ on ice, with vigorous vortexing every $2-3 \mathrm{~min}$. Then the cell lysates were centrifuged in a table-top centrifuge for $5 \mathrm{~min}$ at $16200 \mathrm{~g}$. The supernatant was collected as a cytosolic fraction. The pellets were washed once with buffer 1 , then resuspended in $100 \mu \mathrm{L}$ of buffer 2 (20 mM HEPES pH 7.5, 1,1 mM EDTA, $420 \mathrm{mM} \mathrm{NaCl}, 1 \mathrm{mM}$ DTT, PMSF, and Complete (Roche, Switzerland)), and incubated on ice for 15 min with vigorous vortexing every 2-3 min, followed by centrifugation for $5 \mathrm{~min}$ at $16200 \mathrm{~g}$. After that the supernatant was combined with $100 \mu \mathrm{L}$ of buffer 3 (20 mM HEPES pH 7.5, 1,1 mM EDTA, $100 \mathrm{mM} \mathrm{KCl}, 20 \%$ glycerol, $1 \% \mathrm{NP}$ 40, $1 \mathrm{mM}$ DTT, Complete, and PMSF), representing nuclear proteins. Isolated cytosolic and nucleic proteins were both stored at $-80{ }^{\circ} \mathrm{C}$. The separation was validated by immunoblotting of anti-tubulin and antilamin.

Statistical Analysis. Bar graphs represent means \pm SD. Statistical analyses were performed using GraphPad Prism (GraphPad Software Inc., La Jolla, CA, USA). Statistical differences among the treatment groups were compared using one-way ANOVA with Dunnet's multiple comparisons tests. $P$-values of $<0.05$ were considered as significant. Nonlinear regression (sigmoidal dose response) was used to calculate $\mathrm{IC}_{50}$ values.

\section{ASSOCIATED CONTENT}

\section{S Supporting Information}

The Supporting Information is available free of charge on the ACS Publications website at DOI: 10.1021/acs.jnatprod.7b00503.

Supplemental figures (DOC)

\section{AUTHOR INFORMATION}

\section{Corresponding Author}

*Tel: +43-1-4277-55270. Fax: +43-1-4277-55969. E-mail: verena.dirsch@univie.ac.at.

ORCID

Atanas G. Atanasov: 0000-0003-2545-0967

Verena M. Dirsch: 0000-0002-9261-5293

Notes

The authors declare no competing financial interest.

\section{ACKNOWLEDGMENTS}

This work was financially supported by the Austrian Science Fund (FWF), S10703 and S10704 (NFN "Drugs from Nature Targeting Inflammation"), and in part also by an advancement scholarship of the Austrian Federal Ministry of Science, Research and Economy (to C.M.).

\section{REFERENCES}

(1) Rehman, S. U.; Choe, K.; Yoo, H. H. Molecules 2016, $21,331$.

(2) Bhat, R.; Karim, A. A. Fitoterapia 2010, 81, 669-679.

(3) Tran, T. V. A.; Malainer, C.; Schwaiger, S.; Atanasov, A. G.; Heiss, E. H.; Dirsch, V. M.; Stupper, H. J. Nat. Prod. 2014, 77, 483488.

(4) De Martin, R.; Hoeth, M.; Hofer-Warbinek, R.; Schmid, J. A. Arterioscler., Thromb., Vasc. Biol. 2000, 20, E83-88.

(5) Collins, T.; Read, M. A.; Neish, A. S.; Whitley, M. Z.; Thanos, D.; Maniatis, T. FASEB J. 1995, 9, 899-909.

(6) Zhang, H.; Sun, S. C. Cell Biosci. 2015, 5, 63.

(7) Gilmore, T. D. Oncogene 2006, 25, 6680-6684.

(8) Hajjouli, S.; Chateauvieux, S.; Teiten, M. H.; Orlikova, B.; Schumacher, M.; Dicato, M.; Choo, C. Y.; Diederich, M. Molecules 2014, 19, 14649-14666.

(9) Han, Y. M.; Woo, S. U.; Choi, M. S.; Park, Y. N.; Kim, S. H.; Yim, H.; Yoo, H. H. Arch. Pharmacal Res. 2016, 39, 421-428.

(10) Guo, Z.; Vangapandu, S.; Sindelar, R. W.; Walker, L. A.; Sindelar, R. D. Curr. Med. Chem. 2005, 12, 173-190.

(11) Wertheimer, S. J.; Myers, C. L.; Wallace, R. W.; Parks, T. P. J. Biol. Chem. 1992, 267, 12030-12035.

(12) Ohh, M.; Takei, F. Leuk. Lymphoma 1996, 20, 223-228.

(13) Chen, J.; Maltby, K. M.; Miano, J. M. Biochem. Biophys. Res. Commun. 2001, 281, 475-482.

(14) Ghersa, P.; van Huijsduijnen, R. H.; Whelan, J.; DeLamarter, J. F. J. Biol. Chem. 1992, 267, 19226-19232.

(15) Hasan, A.; Cotobal, C.; Duncan, C. D.; Mata, J. PLoS Genet. 2014, 10, e1004684.

(16) Silva, R. L.; Lopes, A. H.; França, R. O.; Vieira, S. M.; Silva, E. C.; Amorim, R. C.; Cunha, F. Q.; Pohlit, A. M.; Cunha, T. M. J. Nat. Prod. 2015, 78, 241-249.

(17) Alao, J. P. Mol. Cancer 2007, 6, 24.

(18) Zhao, J.; Tenev, T.; Martins, L. M.; Downward, J.; Lemoine, N. R. J. Cell Sci. 2000, 113, 4363-4371.

(19) Giaccia, A. J.; Kastan, M. B. Genes Dev. 1998, 12, 2973-2983.

(20) Geley, S.; Kramer, E.; Gieffers, C.; Gannon, J.; Peters, J. M.; Hunt, T. J. Cell Biol. 2001, 153, 137-48.

(21) Fresno, M.; Gonzales, A.; Vazquez, D.; Jiménez, A. Biochim. Biophys. Acta, Nucleic Acids Protein Synth. 1978, 518, 104-112.

(22) Considine, R. T.; Willingham, W., Jr.; Chaney, S. G.; Wyrick, S.; Hall, I. H.; Lee, K. H. Eur. J. Biochem. 1983, 132, 157-163.

(23) Willingham, W.; Jr; Stafford, E. A.; Reynolds, S. H.; Chaney, S. G.; Lee, K. H.; Okano, M.; Hall, I. H. Biochim. Biophys. Acta, Nucleic Acids Protein Synth. 1981, 654, 169-174.

(24) Liou, Y. F.; Hall, I. H.; Okano, M.; Chaney, S.G. J. Pharm. Sci. 1982, 71, 430-435.

(25) Hall, I. H.; Liou, Y. F.; Lee, K. H.; Chaney, S. G.; Willingham, W., Jr. J. Pharm. Sci. 1983, 72, 626-630. 
(26) Silva, R. L.; Lopes, A. H.; França, R. O.; Vieira, S. M.; Silva, E. C.; Amorim, R. C.; Cunha, F. Q.; Pohlit, A. M.; Cunha, T. M. J. Nat. Prod. 2015, 78, 241-249.

(27) Kim, J. A.; Lau, E. K.; Pan, L.; De Blanco, E. J. Anticancer Res. 2010, 30, 3295-3300.

(28) Lau, S. T.; Lin, Z. X.; Leung, P. S. Br. J. Cancer 2010, 102, 583593.

(29) Turpaev, K.; Welsh, N. Biochem. Biophys. Res. Commun. 2015, 460, 868-872.

(30) Ren, D.; Villeneuve, N. F.; Jiang, T.; Wu, T.; Lau, A.; Toppin, H. A.; Zhang, D. D. Proc. Natl. Acad. Sci. U. S. A. 2011, 108, 1433-1438.

(31) Olayanju, A.; Copple, I. M.; Bryan, H. K.; Edge, G. T.; Sison, R. L.; Wong, M. W.; Lai, Z. Q.; Lin, Z. X.; Dunn, K.; Sanderson, C. M.; Alghanem, A. F.; Cross, M. J.; Ellis, E. C.; Ingelman-Sundberg, M.; Malik, H. Z.; Kitteringham, N. R.; Goldring, C. E.; Park, B. K. Free Radical Biol. Med. 2015, 78, 202-212.

(32) Beutler, J. A.; Kang, M. I.; Robert, F.; Clement, J. A.; Pelletier, J.; Colburn, N. H.; McKee, T. C.; Goncharova, E.; McMahon, J. B.; Henrich, C. J. J. Nat. Prod. 2009, 72, 503-506.

(33) Vartanian, S.; Ma, T. P.; Lee, J.; Haverty, P. M.; Kirkpatrick, D. S.; Yu, K.; Stokoe, D. Mol. Cell. Proteomics 2016, 15, 1220-1231.

(34) Fukamiya, N.; Lee, K. H.; Muhammad, I.; Murakami, C.; Okano, M.; Harvey, I.; Pelletier, J. Cancer Lett. 2005, 220, 37-48.

(35) Valeriote, F. A.; Corbett, T. H.; Grieco, P. A.; Moher, E. D.; Collins, J. L.; Fleck, T. J. Oncol Res. 1998, 10, 201-208.

(36) Kupchan, S. M.; Britton, R. W.; Lacadie, J. A.; Ziegler, M. F.; Sigel, C. W. J. Org. Chem. 1975, 40, 648-654.

(37) Davis, A. R.; Gohara, D. W.; Yap, M. N. Proc. Natl. Acad. Sci. U. S. A. 2014, 111, 15379-15384.

(38) Kannan, K.; Kanabar, P.; Schryer, D.; Florin, T.; Oh, E.; Bahroos, N.; Tenson, T.; Weissman, J. S.; Mankin, A. S. Proc. Natl. Acad. Sci. U. S. A. 2014, 111, 15958-15963.

(39) Schiller, H. B.; Szekeres, A.; Binder, B. R.; Stockinger, H.; Leksa, V. Mol. Biol. Cell 2009, 20, 745-756.

(40) Fakhrudin, N.; Waltenberger, B.; Cabaravdic, M.; Atanasov, A. G.; Malainer, C.; Schachner, D.; Heiss, E. H.; Liu, R.; Noha, S. M.; Grzywacz, A. M.; Mihaly-Bison, J.; Awad, E. M.; Schuster, D.; Breuss, J. M.; Rollinger, J. M.; Bochkov, V.; Stuppner, H.; Dirsch, V. M. Br. J. Pharmacol. 2014, 171, 1676-1686.

(41) Heiss, E. H.; Schachner, D.; Zimmermann, K.; Dirsch, V. M. Redox Biol. 2013, 1, 359-365. 